\title{
The U.S. System for Measuring Cross-Border Investment in Securities: A Primer with a Discussion of Recent Developments
}

William L. Griever, Gary A. Lee, and Francis E. Warnock, of the Board's Division of International Finance, prepared this article. Chad Cleaver provided research assistance.

One of the most striking developments in international finance in recent years has been the enormous expansion in cross-border securities transactions and holdings, accompanied by a decline in the relative importance of international bank lending. In the past decade, for example, the share of U.S. equities transactions involving foreign investors rose from less than 1 percent to more than 20 percent. In contrast, over the same period, the share of bank lending in U.S. cross-border positions decreased by half. Crossborder securities flows are now large enough to significantly influence national markets and to affect the overall health of the international financial system.

The shift in the nature of cross-border financing has heightened interest in the quality and timeliness of the systems used by the United States and other countries to measure international securities flows and holdings. Ideally, the U.S. measurement system should provide information on the size of crossborder holdings, the geographic composition of holdings, the types of securities held, the extent of foreign ownership of U.S. companies, and developing trends. It should also help in understanding what drives portfolio flows into and out of the United States and the effect of these flows on exchange rates. As this article will show, the data collected by the United States can address some of these topics better than others.

The article is intended as a primer on the U.S. system for measuring cross-border securities investment. It begins with an overview of the data collection system and a look at some recent trends in cross-border holdings and transactions. It then discusses aspects of the system's design and implications of the design for data interpretation. The article concludes with a discussion of anticipated changes to the U.S. system and of the way those changes are being influenced by international efforts to improve the availability, timeliness, and quality of data on cross-border securities holdings worldwide.

\section{OVERVIEW OF THE U.S. SYSTEM}

The United States collects data on cross-border portfolio investment through the Treasury International Capital (TIC) reporting system. ${ }^{1}$ The detail of information collected and the frequency of collection vary depending on the type of investment being measured.

Cross-border holdings of long-term securities (original term to maturity of more than one year) are measured at market value through periodic benchmark surveys of custodians, issuers, and investors; data are collected at the security level (that is, information is reported separately for each security). Cross-border transactions in equities and long-term debt securities are measured at market value through monthly reports filed by transactors (mainly brokerdealers); data are collected at the aggregate level, by country (for simplicity, such data are referred to throughout this article as aggregate data).

Foreign holdings of U.S. short-term securities are measured in the aggregate, at face value, through monthly reports filed by banks and brokers and quarterly reports filed by corporate borrowers. ${ }^{2}$ Some

1. Portfolio investment is defined as ownership or control, by a single investor or an affiliated group, of less than 10 percent of the voting equity of an incorporated business enterprise or an equivalent interest in an unincorporated enterprise. Ownership or control, by a single investor or an affiliated group, of 10 percent or more of the voting equity of an incorporated business enterprise or an equivalent interest in an unincorporated enterprise is considered direct investment. Direct investment is measured by the Department of Commerce's Bureau of Economic Analysis. This article deals only with portfolio investment.

2. U.S. securities are defined as securities issued by institutions resident in the United States, with the exception of securities issued by official international and regional organizations, which are categorized as foreign regardless of their location. Neither the currency in which a security is denominated nor the exchange on which a security trades determines whether a security is domestic or foreign. Thus, a security issued in Germany by a U.S.-resident firm that is denominated in euros is a U.S. security, while a security issued by a Canadian firm that trades in the United States and is denominated in U.S. dollars is a 
categories of short-term holdings are measured separately, while others are included indistinguishably in "catch-all" categories of short-term liabilities. U.S. holdings of foreign short-term securities are measured in the aggregate, at face value, through monthly reports filed by banks and brokers and quarterly reports filed by custodians and investors; all such holdings are commingled with other types of assets, such as time and demand deposits.

Measurement of cross-border activity in long-term securities is the focus of this article. For a description of the measurement of cross-border activity in shortterm securities and other types of assets and liabilities, see the box "TIC Reporting System for Portfolio Investment Items Other Than Long-Term Securities."

The monthly aggregate transactions reports and the periodic benchmark surveys form a complementary system. The monthly reports provide timely data on cross-border securities transactions, but the information is less detailed than that provided by the benchmark surveys-and probably somewhat less accurate because the monthly reports collect aggregate rather than security-level data. The surveys, while providing greater detail and presumably greater accuracy, cannot be produced in a time frame that could be useful for immediate policymaking purposes.

Data from the benchmark surveys, in combination with the monthly transactions data, are the primary source for the Bureau of Economic Analysis's estimates of holdings in the annual international investment position presentation. The BEA also uses the data in calculating investment income and financial flows in the U.S. balance of payments.

Data collected through the TIC system are publicly available on the Department of the Treasury's web site, at http://www.ustreas.gov/tic/. ${ }^{3}$ Time series derived from the monthly and quarterly reports of transactions in long-term securities and holdings of short-term securities and of other types of crossborder financial transactions are posted, in aggregate form, with a two-month lag. Findings from the most recent benchmark surveys of holdings of long-term securities are also posted on the web site.

Many of the TIC data aggregates are published in the Capital Movements section of the quarterly Treasury Bulletin. Selected data aggregates are also published in the Federal Reserve Bulletin. The BEA

foreign security. American Depositary Receipts (ADRs) are considered foreign securities because, although they are issued by U.S. institutions, their purpose is to serve as proxies to facilitate the trading of the foreign securities the ADRs represent.

3. The Department of the Treasury has the legal authority to collect data on cross-border portfolio financial transactions and holdings. However, Treasury has entrusted operational responsibility for the collection of these data to the Federal Reserve System. publishes selected data as well as compilations derived from TIC data in the Department of Commerce's Survey of Current Business.

\section{CROSS-BORDER HOLDINGS \\ OF LONG-TERM SECURITIES}

\section{Data Collection}

Benchmark surveys of cross-border holdings of longterm securities have been carried out at infrequent intervals. Surveys of foreign holdings of U.S. longterm securities (known as liabilities surveys) have been conducted at approximately five-year intervals since year-end 1974. Surveys of U.S. holdings of foreign long-term securities (known as asset surveys) have been conducted as of the end of March 1994 and year-end $1997 . .^{4}$

Both asset and liabilities surveys collect information at the individual security level, thus allowing for detailed editing and analysis of reported data. Although both types of surveys are designed to be as comprehensive as possible, the legal authority to collect data extends only to U.S.-resident entities, with implications that are discussed later.

\section{Liabilities Surveys}

Liabilities surveys collect data on foreign holdings of U.S. long-term securities from two types of reporters: U.S.-resident firms that issue securities and U.S.resident custodians (typically banks and brokerdealers) that hold U.S. securities on behalf of foreign owners.

Custodians are the primary source of data for liabilities surveys because U.S.-resident firms that issue securities usually have little information about the actual owners of their securities. U.S. securities are typically registered on the books of the firms that issue them in "street name" - that is, in the name of the custodian of the securities - not in the name of the actual investor. In contrast, custodians know if they are holding securities on behalf of a foreignresident firm or individual.

Issuers report only foreign holdings that are registered directly on their books (that is, no U.S. custodian is used) or debt securities they have issued in unregistered "bearer" form. Unregistered securities

4. Several asset and liabilities surveys were conducted before the advent of the "modern" survey system in 1974. These surveys are described in the box "History of the U.S. System for Measuring Cross-Border Securities Holdings." 


\section{TIC Reporting System for Portfolio Investment Items Other Than Long-Term Securities}

The TIC system collects data on cross-border holdings of several types of portfolio capital besides the long-term securities that are the focus of this article.

\section{Short-Term Instruments}

This category encompasses such instruments as commercial paper, U.S. Treasury bills, short-term obligations of U.S. government corporations and U.S. government-sponsored agencies, bankers and trade acceptances, and marketable notes (including short-term tranches under medium-term note arrangements); certificates of deposit, regardless of maturity, are reported as marketable short-term instruments if negotiable and as deposits if non-negotiable. Only U.S. Treasury bills, short-term U.S. government agency issues, and U.S.-issued negotiable CDs that are held in custody for foreigners are reported as distinct categories. Other shortterm U.S. liabilities and all foreign short-term instruments held by U.S. residents are not identified separately by type of instrument; rather, they are reported in aggregate categories of "other" liabilities and claims.

Short-term securities are debt instruments with an original term to maturity of one year or less. Holdings are reported monthly or quarterly, in aggregate form, by banks, broker-dealers, and nonfinancial firms. Amounts are reported by country, at face value. Reporting at face value, as opposed to market value, as is done for long-term securities, is appropriate because prices of short-term securities typically do not fluctuate much.

Outstanding face amounts of expressly identified U.S. short-term securities held by foreigners as of June 30 , 2001, were as follows: Treasury bills, $\$ 156.4$ billion; government agency issues, $\$ 60.1$ billion; and negotiable CDs, $\$ 24.9$ billion.

\section{Non-Securities}

The TIC system also collects data on non-securities - such items as deposits, loans, and trade receivables. Collection procedures differ for banking and nonbanking firms.
Banking firms. Data on U.S.-booked outstanding claims and liabilities with foreign residents, including amounts of short-term instruments held in custody for customers, are reported via a combination of monthly, quarterly, and semiannual reports. ${ }^{1}$ Amounts are reported by major type of item (such as deposits and loans) and by major category of foreign "resident" (such as official institutions, unaffiliated foreign banks, own foreign banking offices, and "other" foreigners as a group).

The data are collected from banks in the United States (including branches and agencies of foreign-based banks), other depository institutions, bank and financial holding companies, and securities brokers and dealers in the United States. Currently, entities whose claims and liabilities positions with foreign residents total $\$ 50$ million or more as of the reporting date (or at least $\$ 25$ million with respect to a single country) must file reports. As of June 30, 2001, the 425 firms on the reporting panel reported aggregate claims of $\$ 1,284$ billion and aggregate liabilities of $\$ 1,628$ billion vis-à-vis foreigners.

Nonbanking firms. Data on claims and liabilities positions with unaffiliated foreigners are collected quarterly. The data cover such instruments as loans and deposits as well as commercial positions in such instruments as trade payables and receivables.

The data are collected from importers and exporters, industrial and commercial concerns, insurance and other financial entities (excluding depository institutions and broker-dealers), and similar firms. Currently, all entities in the reporting population whose quarter-end balance for either claims or liabilities is $\$ 10$ million or more must report. As of June 30, 2001, the approximately 300 firms on the reporting panel together reported outstanding claims on foreigners of $\$ 98$ billion and liabilities to foreigners of $\$ 69$ billion.

1. Monthly reports cover respondents' own dollar-denominated claims and liabilities and their custodial holdings of U.S. short-term instruments for foreign clients; quarterly reports cover respondents' own claims and liabilities denominated in foreign currencies and their custodial holdings of shortterm instruments representing U.S. clients' claims on foreigners; and semiannual reports cover dollar-denominated claims and liabilities vis-à-vis countries not listed separately on the monthly reporting forms. are issued abroad only (they have not been issued in the United States since 1984), and purchasers are not required to identify themselves. U.S. entities usually do not have information about the owners of unregistered securities, and issuers are instructed to report such holdings as presumed foreign, country unknown.

Reporting on the liabilities surveys (as on all TIC surveys and reports) is mandatory, with both fines and imprisonment possible for willful failure to report. For the most recent survey, conducted as of March 31, 2000, firms with less than $\$ 20$ million in total reportable foreign holdings were exempt. ${ }^{5}$ All

5. The International Investment and Trade in Services Survey Act (22 U.S.C. 3101 et seq.) requires that comprehensive benchmark surveys of foreign portfolio investment in the United States be conducted at least once every five years. After notification to relevant congressional committees, the most recent survey was conducted five years and three months after the previous survey to avoid imposing a reporting requirement that coincided with respondents' Y2K-related efforts. 


\section{History of the U.S. System for Measuring Cross-Border Securities Holdings}

Early interest in measuring cross-border securities activities focused primarily on foreign holdings of U.S. securities. The first measurement effort was an 1853 Department of the Treasury survey of foreign holdings of U.S. public and private securities conducted in response to congressional concern about the increasing level of U.S. debt held by foreigners. The survey showed that foreigners owned $\$ 222$ million in U.S. securities, 19 percent of total outstanding U.S. securities at that time and 46 percent of outstanding federal government securities. An 1869 study by the Treasury Special Commissioner of the Revenue showed U.S. indebtedness to foreign entities at $\$ 1.4$ billion, including $\$ 1$ billion in U.S. government securities and $\$ 100$ million in state debt.

In 1934, in connection with the banking emergency, the United States began to collect monthly data on transactions in long-term securities and monthly and quarterly data on other financial flows (such as bank and nonbank lending and borrowing) and on holdings of short-term financial instruments. This collection program, known as the Treasury International Capital (TIC) reporting system, began as an expansion of a voluntary reporting program instituted in the late 1920s by the Federal Reserve Bank of New York to obtain figures on U.S. banks' positions with foreigners.

In addition to the TIC system, surveys of foreign holdings of U.S. long-term securities continued intermittently. The Department of Commerce conducted two surveys during the Depression to "provide . . . an adequate statistical basis for estimating annual interest and dividend payments by the United States to investors residing in foreign countries." Foreign holdings of U.S. securities were found to be $\$ 4.5$ billion at the end of 1937 , compared with $\$ 2.1$ billion at the end of 1934 .

Two surveys were conducted during the World War II era. The first, by the Treasury Department, found foreign holdings of U.S. securities to be some $\$ 2.7$ billion as of June 14, 1941. (As a wartime measure, the United States froze U.S. assets belonging to the $A$ xis countries as well as countries invaded by Germany or Japan.) The other survey took place in 1943, when the Treasury Department conducted the first survey of U.S. ownership of foreign assets, in this case assets of all types. The primary purpose of the survey was to help U.S. residents recover or seek reparations for foreign assets that may have been confiscated or destroyed during the war. ${ }^{1}$

In 1945, the legal basis for the TIC system was widened by the Bretton Woods Agreements Act to enable the United States to comply with International Monetary Fund needs for information on U.S. balance of payments and official monetary reserves.

The first modern benchmark survey measured foreign holdings of U.S. long-term securities as of year-end 1974. Prompting the survey initially was public concern about the possible effects on the economy of the rise in investments in the United States by European and Japanese investors; later, concern shifted to the oil-producing countries, which had begun to accumulate substantial investable sums as a result of increased oil income. Without benchmark surveys, the TIC system could not accurately identify the countries that were holding U.S. securities or provide much information on the actual securities being purchased.

To address these shortcomings, Congress passed the Foreign Investment Study Act of 1974 (Public Law 93-479), which evolved into the current enabling legislation, the International Investment and Trade in Services Survey Act (22 U.S.C. 3101 et seq.). The latter act stipulates, among other things, that a comprehensive, benchmark survey of foreign portfolio investment in the United States be conducted at least once every five years and that information collected under the authority of the act be published for use by the general public and by U.S. government agencies.

1. The portion of the preceding discussion pertaining to surveys of foreign holdings of U.S. securities was drawn from Department of the Treasury, Report on Foreign Portfolio Investment in the United States as of December 31,1984 , chap. 6 . firms that are thought to have a reasonable likelihood of meeting the reporting requirements are sent a copy of the survey instructions $(1,445$ firms for the most recent survey). In addition, notice is published in the Federal Register, which constitutes legal notification of the survey's reporting requirements.

For the most recent liabilities survey, data were received from 208 custodians and 289 issuers. Whereas issuers on average reported relatively low levels of foreign holdings, many custodians reported very high levels. Indeed, custodians accounted for 94 percent of total reported foreign holdings, as measured in terms of market value, and the six largest custodians together accounted for approximately 60 percent of the total (more than $\$ 2$ trillion).

Some 2.2 million data records were received, the vast majority in electronic form. Four custodians reported more than 100,000 records each. The data were subjected to extensive verification checks, including comparison with information obtained from commercial and international sources to help verify such items as price, currency of denomination, and amounts reported. The distributional pattern of each submission was analyzed with respect to such variables as the countries of foreign holders and the types of securities held. Questionable data were discussed 
with respondents, and detected errors were corrected. Although most respondents provided high-quality data, at the other extreme, some respondents were required to provide completely revised submissions. The security-level editing greatly improved the quality of data by enabling the detection and correction of many errors; for instance, 133,058 records with an originally reported market value of $\$ 255$ billion were excluded from the survey, most commonly because they were determined to be foreign securities or U.S. short-term securities.

\section{Asset Surveys}

Asset surveys employ the same general approach as liabilities surveys. Data are collected from two types of reporters, in this case, U.S.-resident custodians and U.S. institutional investors. Custodians are again the primary source of information, reporting 97 percent of total U.S. holdings of foreign long-term securities, by market value, on the most recent survey. Institutional investors, such as mutual funds, pension funds, insurance companies, endowments, and foundations, report in detail on their ownership of foreign securities only if they do not entrust the safekeeping of these securities to U.S.-resident custodians. If they do use U.S.-resident custodians, institutional investors report only the name(s) of the custodian(s) and the amount $(s)$ entrusted.

The requirement that institutional investors identify their U.S.-resident custodian(s) has the beneficial side effect of ensuring that all sizable U.S.-resident custodians holding foreign securities are included in the survey, because any custodian identified by an institutional investor is instructed to report. The requirement also makes it possible to check on survey accuracy, as the amount of foreign holdings each custodian should report can be estimated by summing the amounts that institutional investors have entrusted to each custodian.

The asset surveys receive approximately 60 percent fewer data records than the liabilities surveys, but in some ways the asset surveys are more difficult and more complex to conduct: Accurately pricing and categorizing the universe of foreign securities is far more challenging, as the commercial data used to cross-check data on foreign securities are generally less complete than like data for cross-checking data on U.S. securities; custodian data tend to have more errors and omissions in asset surveys compared with liabilities surveys; and unexpected local market quirks can lead to misinterpretations of reported asset data. In addition, accurately determining the currency in which foreign debt securities are denominated, though essential for calculating U.S. dollar equivalents, is sometimes difficult.

\section{Preliminary Findings from the} March 2000 Liabilities Survey

The most recent liabilities survey showed foreign holdings of U.S. long-term securities of $\$ 3.6$ trillion at the end of March 2000 , compared with $\$ 1.2$ trillion measured by the year-end 1994 survey. ${ }^{6}$ The tripling of foreign holdings reflects substantial net purchases of U.S. securities in the late 1990 s as well as sizable gains in the value of U.S. equities over the period.

Foreign Holdings, by Type of Instrument and Country

The relative gains in U.S. equity prices helped shift the composition of foreign holdings of U.S. long-term securities over the five years between surveys, as there was no corresponding appreciation in the value of debt securities. In 1994, foreign investors held far more U.S. debt than equity (table 1). By 2000, foreigners' equity holdings were close to their holdings of debt, though considerable differences remained across countries. For example, of the countries listed in table 1, Canada and the European countries held more equity than debt in 2000, while the Asian countries and the offshore financial centers of Bermuda and the Cayman Islands held more debt than equity.

Over the past two decades, residents of Japan and the United Kingdom have consistently led residents of other countries in terms of their holdings of U.S. long-term securities. Holdings by residents of Japan were the greatest in 1989 and 1994, while holdings by residents of the United Kingdom were the largest in 1984 and 2000.

Although the proportional increase in holdings between 1994 and 2000 was relatively uniform across countries, the holdings of some countries rose spectacularly. For example, Luxembourg's holdings increased twentyfold, and China's increased fivefold.

The magnitude of holdings by residents of Luxembourg in 2000 ( $\$ 106$ billion) relative to that country's annual gross domestic product ( $\$ 18$ billion) highlights an important shortcoming of the liabilities sur-

6. The March 2000 data presented here are based on preliminary data. A full report on the March 2000 liabilities survey will be posted on the Department of the Treasury's web site in the near future. 
1. Market value of foreign holdings of U.S. long-term securities, by country, December 31, 1994, and March 31, 2000 Billions of dollars

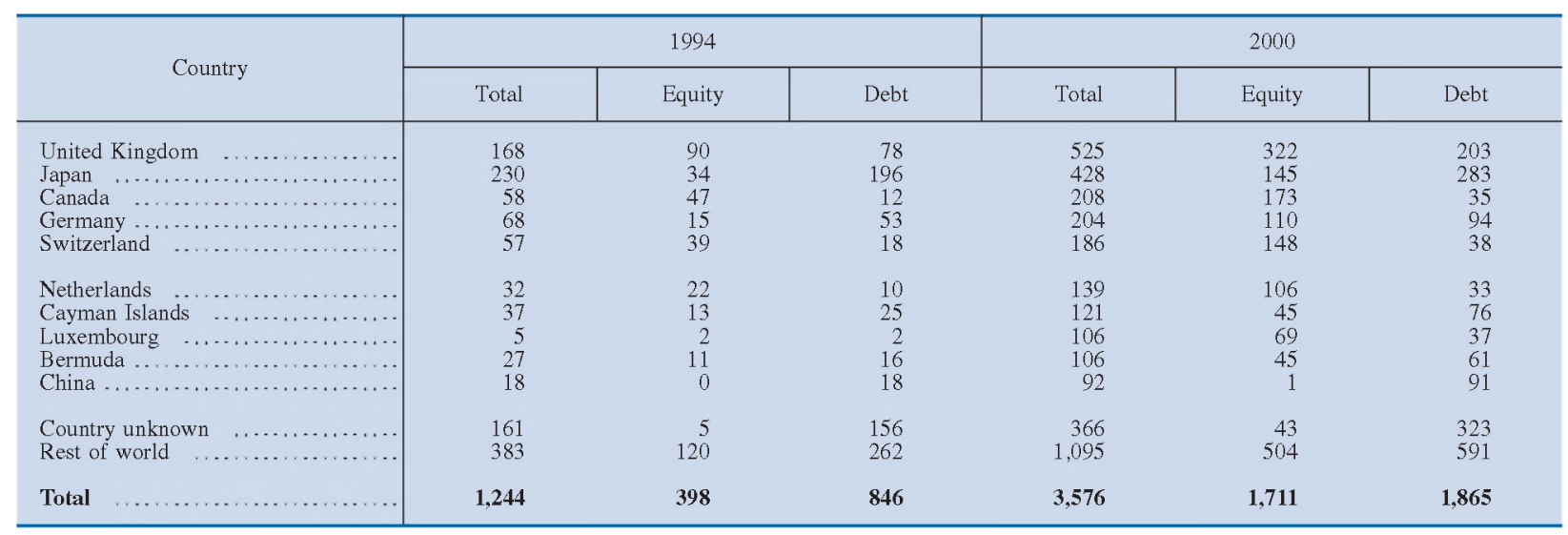

Note. In this and subsequent tables, components may not sum to totals because of rounding.

vey data - their custodial center bias. Luxembourg is a major custodial center, and significant holdings are attributed to that country that are actually holdings of residents of other countries.

The source of this custodial center bias can be seen in the following example. A resident of Germany may buy a U.S. security and place it in the custody of a Swiss bank. The Swiss bank will then normally employ a U.S.-resident custodian bank to act as its foreign subcustodian for the security to facilitate settlement and custody operations. Because the legal authority to collect information by means of the surveys extends only to U.S.-resident entities, the U.S.-resident bank acting as subcustodian for the Swiss bank will report the security on the survey. And because the U.S. bank will typically know only that it is holding the security on behalf of a Swiss bank, it will report the security as Swiss held.

Among the countries listed in table 1, the United Kingdom, Switzerland, the Cayman Islands, Luxembourg, and Bermuda are financial centers where securities owned by residents of other countries are held in custody. Although the benchmark surveys' country attribution of foreign investment in U.S. securities is clearly imperfect, the survey data have historically been better at determining country attribution than the monthly flow data (as is discussed later).

The $\$ 323$ billion in debt securities categorized as "Country unknown" in table 1 points to another difficulty in attributing ownership of U.S. securities to particular countries. Owners of U.S. debt securities issued abroad in the form of bearer (unregistered) securities need not identify themselves, and therefore neither the issuers nor U.S. custodians typically have information about these owners. Thus, no country attribution is possible unless the securities are entrusted to U.S. custodians for safekeeping, an uncommon occurrence.

\section{Foreign Holdings of U.S. Securities in Perspective}

Comparison of foreign holdings of U.S. Iong-term securities with other metrics provides perspective on these holdings. One such standard is U.S. holdings of foreign securities: As of March 31, 2000, when foreign holdings of U.S. long-term securities stood at $\$ 3.6$ trillion, U.S. holdings of foreign long-term securities totaled an estimated $\$ 2$ trillion.

Another measure is growth over time. Foreign portfolio investment in U.S. securities began modestly, with the level of investment actually decreasing between 1914 and $1934 .^{7}$ Since 1934, the level of investment has increased significantly, and the rate of increase has accelerated: Between 1934 and 1965, the average annual rate of increase was approximately 8 percent; it reached 14 percent between 1965 and 1984 and was an impressive 17 percent between 1984 and March 2000. As previously noted, the increasing level of investment reflects both gains in the value of securities held and increases in foreign purchases of U.S. securities.

A third useful comparison is the value of foreign holdings of various types of U.S. securities as a

7. Estimates of foreign portfolio investment in the United States before the 1974 benchmark liabilities survey are from Cleona Lewis, America's Stake in International Investments (Brookings Institution. 1938); U.S. Department of the Treasury, Census of Foreign-Owned Assets in the United States (Government Printing Office, 1945); and various issues of U.S. Department of Commerce, Survey of Current Business. 
proportion of the total market value outstanding (table 2). Between 1994 and 2000, the proportion of U.S. securities held by foreign owners increased for every type of securitiy. The increase was greatest for Treasury securities, largely because of the very small increase in the value of long-term Treasury securities outstanding: Whereas the value of outstanding equities more than tripled over the period and the value of outstanding corporate and municipal debt and government agency debt increased substantially, the value of outstanding Treasury securities barely increased. Thus, although the percentage increase in the value of foreign holdings was less for Treasuries than for other types of securities, the proportion of Treasury securities held by foreigners increased markedly.

A final measure that puts foreign holdings of longterm securities in perspective is the share of total U.S. portfolio liabilities to foreigners accounted for by foreign holdings of U.S. securities. Over the past decade, foreign holdings of U.S. securities have become an increasingly important component of U.S. portfolio liabilities to foreigners, rising from 49 percent to 65 percent of the total from year-end 1989 to year-end 2000. In contrast, the proportion of total U.S. portfolio liabilities accounted for by U.S. banking liabilities declined over the period, from 36 percent to 19 percent.

\section{CROSS-BORDER TRANSACTIONS IN LONG-TERM SECURITIES}

\section{Data Collection}

Monthly reports of cross-border transactions in longterm securities supplement the periodic benchmark surveys. The monthly data are used in the construction of the U.S. balance of payments accounts, in the formulation of international financial and monetary policy, and in tracking developments in international markets. The monthly reporting panel comprises some 250 banks, securities dealers, and other enterprises in the United States that undertake transactions directly with foreign residents.

Gross purchases and sales of U.S securities are reported in several categories-Treasury bonds and notes, federal agency issues, corporate and municipal debt, and corporate equities. Transactions in foreign securities are reported in only two categoriesforeign debt and foreign equities. Aggregate transactions in U.S. issues by foreign official institutions are reported separately.
2. Market value of foreign holdings of U.S. long-term securities, by type of security, selected years. 1974-2000

Billions of dollars, except as noted

\begin{tabular}{|c|c|c|c|}
\hline Year & $\begin{array}{c}\text { Total } \\
\text { outstanding }\end{array}$ & $\begin{array}{l}\text { Foreign } \\
\text { owned }\end{array}$ & $\begin{array}{l}\text { Percent } \\
\text { foreign } \\
\text { owned }\end{array}$ \\
\hline \multirow{8}{*}{ 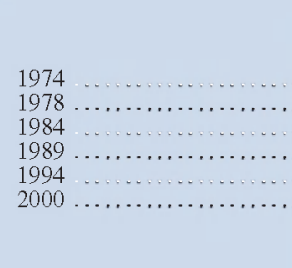 } & \multicolumn{3}{|c|}{ Cerporale équily } \\
\hline & \multirow{6}{*}{$\begin{array}{r}663 \\
1,012 \\
1,899 \\
4,212 \\
7,183 \\
23,038\end{array}$} & \multirow{6}{*}{$\begin{array}{r}25 \\
48 \\
105 \\
275 \\
398 \\
1,711\end{array}$} & \multirow{6}{*}{$\begin{array}{l}3.8 \\
4.7 \\
5.5 \\
6.5 \\
5.5 \\
7.4\end{array}$} \\
\hline & & & \\
\hline & & & \\
\hline & & & \\
\hline & & & \\
\hline & & & \\
\hline & \multicolumn{3}{|c|}{ Corporate aud municipal deht } \\
\hline \multirow{7}{*}{$\begin{array}{l}1974 \\
1978 \\
1984 \ldots \ldots \ldots \ldots \ldots \\
1989 \ldots \ldots \ldots \ldots \ldots \ldots \ldots \\
1994 \ldots \ldots \ldots \ldots \ldots \ldots \ldots \\
2000\end{array}$} & \multirow{6}{*}{$\begin{array}{r}458 \\
680 \\
1,149 \\
2,400 \\
3,342 \\
5,404\end{array}$} & \multirow{6}{*}{$\begin{array}{r}\text { n.a. } \\
7 \\
31 \\
190 \\
276 \\
712\end{array}$} & \multirow{6}{*}{$\begin{array}{r}\text { n.a. } \\
1.0 \\
2.7 \\
7.9 \\
8.3 \\
13.2\end{array}$} \\
\hline & & & \\
\hline & & & \\
\hline & & & \\
\hline & & & \\
\hline & & & \\
\hline & \multicolumn{3}{|c|}{ Marketable IIS.S. Treasury securities } \\
\hline \multirow{6}{*}{$\begin{array}{l}1974 \\
1978 \\
1984 \\
1989 \\
1994 \\
2000\end{array}$} & \multirow{5}{*}{$\begin{array}{r}163 \\
326 \\
873 \\
1,599 \\
2,392 \\
2,508\end{array}$} & \multirow{5}{*}{$\begin{array}{r}24 \\
39 \\
118 \\
333 \\
464 \\
885\end{array}$} & \multirow{5}{*}{$\begin{array}{l}14.7 \\
12.0 \\
13.5 \\
20.8 \\
19.4 \\
35.3\end{array}$} \\
\hline & & & \\
\hline & & & \\
\hline & & & \\
\hline & & & \\
\hline & \multicolumn{3}{|c|}{ 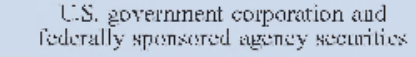 } \\
\hline \multirow{6}{*}{$\begin{array}{l}1974 . \\
1978 \\
1984 \\
1989 \\
1994 . \\
2000\end{array}$} & \multirow{5}{*}{$\begin{array}{r}106 \\
188 \\
529 \\
1,267 \\
2,199 \\
3,968\end{array}$} & \multirow{5}{*}{$\begin{array}{r}\text { n.a. } \\
5 \\
13 \\
48 \\
107 \\
257\end{array}$} & \multirow{5}{*}{$\begin{array}{r}\text { n.a. } \\
2.7 \\
2.5 \\
3.8 \\
4.9 \\
6.7\end{array}$} \\
\hline & & & \\
\hline & & & \\
\hline & & & \\
\hline & & & \\
\hline & \multicolumn{3}{|c|}{ Combiued market } \\
\hline \multirow{6}{*}{$\begin{array}{l}1974 \ldots \ldots \ldots \\
1978 \ldots \ldots \ldots \\
1984 \ldots \ldots \ldots \\
1989 \ldots \ldots \ldots \ldots \\
1994 \ldots \ldots \ldots \\
2000 \ldots \ldots \ldots \\
\ldots\end{array}$} & 1,390 & 67 & 4.8 \\
\hline & 2,206 & 99 & 4.5 \\
\hline & 4,450 & 268 & 6.0 \\
\hline & 9,478 & 847 & 8.9 \\
\hline & 15,116 & 1,244 & 8.2 \\
\hline & 34,918 & 3,576 & 10.2 \\
\hline
\end{tabular}

NoTE. For 2000, data are as of March 31; for all other years, December 31 . n.a. Not available.

Source. Data on amount outstanding for all categories except marketable Treasury securities are from Federal Reserve Statistical Release Z.1, Flow of Funds Accounts of the United States. Amount outstanding of marketable Treasury securities, which excludes Treasury bills, is from the Bureau of Public Debt, Monthly Statement of the Public Debt of the United States.

The amount reported is the total payment made or received (the value of the transaction plus or minus commissions and fees). Reporting is mandatory if monthly transactions exceed an established threshold (in January 2001, the threshold was raised from $\$ 2$ million to $\$ 50$ million). The threshold is applicable to either total purchases or total sales in a month; once the threshold is reached for total purchases or total sales, all purchases and sales transactions during that month must be reported. The gross dollar volume of all reported transactions for calendar year 2000 was $\$ 22$ trillion, and gross transactions are on pace to reach $\$ 26$ trillion in 2001 . 
3. Market value of U.S. cross-border transactions in long-term securities, by type of security, 1980-2001 Billions of dollars, annual rate

\begin{tabular}{|c|c|c|c|c|c|}
\hline Type of security & $1980-89$ & $1990-94$ & 1995-99 & 2000 & 2001:H1 \\
\hline 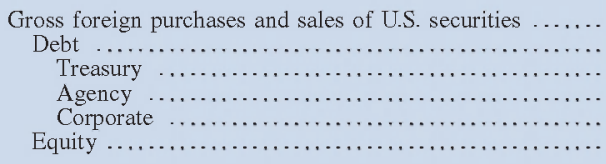 & $\begin{array}{r}1,734 \\
1,515 \\
1,408 \\
45 \\
62 \\
219\end{array}$ & $\begin{array}{r}5,414 \\
4,906 \\
4,524 \\
198 \\
184 \\
508\end{array}$ & $\begin{array}{r}11,715 \\
9,339 \\
8,271 \\
561 \\
507 \\
2,376\end{array}$ & $\begin{array}{r}16,917 \\
9,881 \\
7,803 \\
1,305 \\
773 \\
7,036\end{array}$ & $\begin{array}{r}20,188 \\
13,810 \\
10,531 \\
1,979 \\
1,300 \\
6,378\end{array}$ \\
\hline $\begin{array}{c}\text { Gross US. purchases and sales of foreign securities } \\
\text { Debt } \\
\text { Equity }\end{array}$ & $\begin{array}{r}299 \\
216 \\
83\end{array}$ & $\begin{array}{r}1,577 \\
1,130 \\
447\end{array}$ & $\begin{array}{l}3,756 \\
2,267 \\
1,489\end{array}$ & $\begin{array}{l}5,537 \\
1,923 \\
3,614\end{array}$ & $\begin{array}{l}5,789 \\
2,542 \\
3,247\end{array}$ \\
\hline
\end{tabular}

Note. Figures for 2001:H1 are based on data through June.

\section{Trends}

Cross-border financial flows skyrocketed over the past decade (table 3). Transactions in both U.S. and foreign long-term securities increased sharply, and annual trading volume in 2001 is projected (on the basis of data for the first half of the year) to be four times greater than in the early 1990s and thirteen times greater than in the $1980 \mathrm{~s}$. Trading volume in all instruments has increased, although it is noteworthy that since the mid-1990s, transactions in U.S. Treasuries and in foreign debt have leveled off. In contrast, trading volume in other U.S. debt issues (agency and corporate) as well as U.S. and foreign equities has continued to increase.

Associated with the increased trading volume has been a sharp increase in net acquisitions (table 4). At an annual rate, both net foreign acquisitions of U.S. long-term securities and net U.S. acquisitions of foreign securities are running more than ten times greater in 2001 than in the 1980s. Net foreign acquisitions of U.S. securities have increased sharply, surpassing $\$ 400$ billion in 2000 . Within debt issues, there has been a distinct move from Treasury debt securities to agency and corporate debt as the supply of Treasury issues has dwindled and agencies and some large corporations have increased issuance in response. Net U.S. acquisitions of foreign securities have also increased, recently averaging about $\$ 100$ billion a year, but have been much smaller than net foreign acquisitions of U.S. securities. Two trends in U.S. acquisitions of foreign securities are evident: a distinct decline in net purchases of foreign debt and a sharp increase in the value of foreign equities acquired in stock swaps (discussed later).

\section{NOTES CONCERNING THE SYSTEM'S DESIGN}

Users of the U.S. data on cross-border holdings of and transactions in long-term securities should be aware of the implications of the TIC system's design for data interpretation. In particular, the monthly transactions reports were designed to provide timely information on movements of capital between the United States and foreign countries, primarily for balance of payments purposes. Thus, the system is heavily influenced by balance of payments conventions that might not be readily apparent to the casual user. Those conventions are discussed in some detail in this section. Also discussed are the implications of the treatment of repurchase and securities lending agreements.

\section{Country Attribution}

For balance of payments purposes, the monthly transactions reports were designed to provide information on the country through which a transaction was made, and that country is not necessarily the same as the country in which the security's issuer, purchaser, or seller is resident. For example, if a German resident purchases a U.S. corporate bond through a London office, the transaction is reported as a U.K. purchase of a U.S. corporate bond. Similarly, if a U.S. resident purchases a Thai stock through an intermediary in Hong Kong, the trade is reported as a U.S. purchase of a foreign stock through Hong Kong. This reporting procedure results in a bias not only toward overcounting flows to countries that are major financial centers but also toward undercounting flows to other countries. Users of the transactions data need to be aware of this bias.

The benchmark surveys similarly are not immune to distortions in the attribution of holdings to particular countries. As discussed earlier, in the surveys of foreign holdings of U.S. securities, country attribution is somewhat distorted if multiple custodians are involved in the safekeeping of a security. The degree of error thus caused is unclear, though it is believed to be less than the trading center bias in the 
4. Market value of U.S. cross-border net acquisitions of long-term securities, by type of security, 1980-2001 Billions of dollars, annual rate

\begin{tabular}{|c|c|c|c|c|c|}
\hline Type of security & $1980-89$ & $1990-94$ & 1995-99 & 2000 & 2001:H1 \\
\hline Net foreign acquisitions of US. securities & 51 & 81 & 337 & 461 & 575 \\
\hline Debt ................................... & 44 & $\begin{array}{l}01 \\
77\end{array}$ & 274 & 281 & 420 \\
\hline 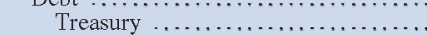 & 24 & 36 & 118 & -54 & -22 \\
\hline Agency $\ldots \ldots \ldots \ldots \ldots \ldots \ldots \ldots \ldots \ldots$ & 4 & 18 & 54 & 153 & 163 \\
\hline Corporate $\ldots \ldots \ldots \ldots \ldots \ldots \ldots$ & 16 & 23 & 102 & 182 & 279 \\
\hline Equity $\ldots \ldots \ldots \ldots \ldots \ldots$ & 7 & 4 & 63 & 180 & 155 \\
\hline TIC $\ldots . . . \cdots$ & 7 & $\begin{array}{c}4 \\
3\end{array}$ & 50 & 180 & $\begin{array}{l}155 \\
152\end{array}$ \\
\hline Stock swaps & 0 & 1 & 13 & 5 & 3 \\
\hline Net U.S. acquisitions of foreign securities & 9 & 65 & 108 & 93 & 132 \\
\hline & 5 & 28 & 34 & 4 & -16 \\
\hline 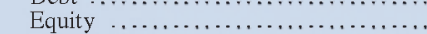 & 4 & 37 & 74 & 89 & 148 \\
\hline TIC $\ldots . . . .$. & 3 & 37 & 26 & 9 & 74 \\
\hline Stock swaps & 1 & 0 & 48 & 80 & 74 \\
\hline
\end{tabular}

NoTE. All data are from the TIC reporting system except those for stock swaps, which are from Security Data Corporation and the Bureau of Economic Analysis. Figures for 2001:H1 are based on data through June.

monthly transactions data for foreign purchases of U.S. securities.

The one set of data for which the country attribution should be completely accurate is that from the benchmark survey of U.S. holdings of foreign securities. The security-level data collected in that survey make it possible to determine precisely the residence of the foreign issuer.

\section{Concept of Residency}

In balance of payments accounting, country attribution is based on residency, that is, on the physical location of an entity. Thus, the U.S. system defines foreign residents as individuals or institutions residing outside the United States on a permanent or long-term basis, regardless of whether they are U.S. citizens. U.S. residents are defined in a like manner. For instance, a U.S. citizen who retires to Spain is a foreigner for purposes of the data. U.S.-resident businesses are those physically located in the United States or legally created in the United States, even if they are subsidiaries or instrumentalities of foreign entities; foreign-resident businesses are similarly defined. Honda USA is considered a U.S. firm, while General Motors Canada is considered foreign.

Knowing that the U.S. system adheres to the balance of payments concept of residency is especially important when interpreting activity vis-à-vis offshore financial centers. In particular, some companies resident in one country create legal entities in another country solely for the purpose of issuing securities (primarily to gain tax and regulatory advantages). These entities, known as foreign financing subsidiaries or special purpose vehicles, are considered residents of the country in which they were created, even if they have no employees or any other recognizable physical presence in that country. In the benchmark surveys, any securities they issue are considered liabilities of their "resident" country, even though the proceeds may be used by and repaid by parent institutions in other countries.

\section{Definition of "Foreign Official Institution"}

As noted earlier, data for foreign official institutions are collected separately from those for other entities, as the motivations of these institutions are believed to be quite different from those of other transactors. The term "foreign official institution" is narrowly defined, however, and should not be construed to be synonymous with "government." For purposes of the TIC system, the term refers only to central banks, ministries of finance, exchange stabilization funds, and similar organizations. Excluded from the category are many other government agencies as well as government-owned corporations, nationalized commercial banks, and government-owned development banks. It should also be noted that the term "private" is sometimes used loosely in U.S. government publications to refer to entities other than foreign official institutions, when "non-foreign official" would be the more accurate term.

\section{Treatment of Stock Swaps}

The monthly transactions reports were designed to capture flows of money associated with transactions in securities conducted through financial intermediaries. In recent years, securities have also been acquired through stock swaps, and in any analysis of net 
securities flows, the TIC transactions data must be supplemented with information on these acquisitions.

Equity financing of cross-border mergers and acquisitions results in stock swaps-the exchange of stock in the target company for stock in the new firm (in the case of a merger) or in the acquiring firm (in the case of an acquisition). For example, when British Petroleum (a U.K. firm) acquired Amoco (a U.S. firm) in an equity-financed deal worth a reported $\$ 48$ billion, holders of stock in now-defunct Amoco were given stock in newly formed BP Amoco, a U.K. firm. Thus, U.S. residents acquired approximately $\$ 48$ billion in U.K. equities. ${ }^{8}$ Because the monthly transactions reports collect data on only market transactions, this stock swap was not recorded by the transactions portion of the TIC system. Nonetheless, stock swaps do represent cross-border acquisitions of equities, and they do, appropriately, appear in the holdings data produced by the benchmark surveys.

As noted earlier, the value of foreign stocks acquired by U.S. residents in stock swap arrangements has increased sharply in recent years. Indeed, the bulk of U.S. residents' acquisitions of foreign stocks in the past few years has been via stock swaps (table 4). Moreover, subsequent sales of foreign equities acquired through stock swaps-a likely occurrence because the equities were in some sense involuntary acquisitions and investors seem to prefer domestic equities-do register in the TIC transactions system. Therefore, any analysis of TIC data without consideration of stock swaps is incomplete and potentially very misleading."

That said, there is some concern about the use of stock swap data because of the unknown quality of the data. At this time, the U.S. government is not compiling official data on these transactions, relying instead on unverified data from nongovernmental sources.

\section{Inclusion of Transaction Costs}

Because the monthly transactions reports were designed to capture the flow of money associated with securities transactions, they include not only the value of securities bought or sold, but also the commission and taxes associated with each transaction. For example, if a foreign resident purchases $\$ 100$ of U.S. equities and pays a $\$ 1$ commission, the TIC system records the transaction as a $\$ 101$ purchase. When a foreigner sells $\$ 100$ of U.S. equities and pays

8. Less the value of Amoco stock held by foreigners.

9. When the BEA publishes the official balance of payments data, it augments the TIC transactions data with data on stock swaps. a $\$ 1$ commission, the transaction is recorded as a $\$ 99$ sale-the amount the foreigner received. If these transactions occur within the same month, the foreigner has no remaining position but the TIC transactions data show a $\$ 2$ net flow into U.S. equities.

Because the TIC system records the actual payment made or received, the inclusion of transaction costs results in a slight overestimation of net purchases. For the official presentation of capital flows data, the BEA adjusts the TIC data for estimated transaction costs.

\section{Estimation of Holdings}

Although the transactions reports were designed primarily to capture balance of payments flows, the monthly data do have other uses. In particular, because of the timeliness of the monthly data-and the infrequency of benchmark surveys - the transactions data have been used to estimate holdings between surveys (see the appendix). Although estimation is possible, the procedure is not without problems. For example, because the transactions data are not collected at the individual security level, it is not clear which price index to use to revalue holdings. Nor, in the case of U.S. holdings of foreign securities, is the country of residence of the issuer known with certainty.

Comparisons of estimated and measured bilateral cross-border securities holdings indicate the extent of the bias in the transactions data toward financial centers such as the United Kingdom and, to a lesser extent, the Caribbean. The bias does not necessarily affect the quality of the aggregate transactions data or analyses of overall foreign purchases of U.S. securities or U.S. purchases of foreign securities. But the bias has important implications for analyses that use bilateral transactions data, including studies of the determinants of capital flows between the United States and a particular country or region and of the effect of such flows on any bilateral exchange rate.

\section{Treatment of Repurchase and Securities Lending Agreements}

Repurchase agreements, or repos, are arrangements whereby the owner of securities sells them for cash with an agreement to repurchase them at a future time (or under specified conditions) at an agreed-upon price. Although some market participants engage in repos to gain control of certain securities, repos are often structured as cash loans for traders seeking to 
finance their portfolios, with the lenders receiving the securities as collateral against borrower default. The securities typically used as collateral are Treasury securities and, to a lesser extent, government agency and corporate debt securities.

Securities lending agreements are similar to repurchase agreements in that the owner transfers title to the securities with an agreement that a like quantity of the same or similar securities will be given back at a future date or under agreed-upon conditions. Again, the borrower provides collateral, but unlike in the case of repos, in which securities are used as collateral, the collateral can be cash, other securities, or bank-issued letters of credit. Many market participants engage in securities lending transactions to obtain securities needed to meet delivery obligations; for example, brokers may need to cover a failed trade, or investors may need to cover a "short" position. Both equity and debt securities are involved in securities lending arrangements.

Repurchase and securities lending agreements pose a problem for the TIC system. Although both arrangements involve the outright sale of securities, they are not so treated in the TIC system. Rather, because the return of the same or similar securities at a set price is pre-agreed and the economic risk of holding the securities continues to reside with the securities lender even while the lender does not own the securities, the transactions are treated as collateralized loans. For the transactions reports, they are not recorded as purchases or sales of securities; for the benchmark surveys, lenders (or their custodians) are instructed to report the securities as continuously held, and borrowers (or their custodians) are instructed not to count them as holdings. (If such transactions are undertaken by banks or brokers for their own accounts, they are recorded elsewhere in the TIC system; otherwise, the transactions are not recorded at all.)

Complicating matters is the fact that borrowers of securities under repo or securities lending agreements have the right to resell the securities. In fact, in the case of securities lending, the purpose of the transaction is usually to obtain a security that is needed for sale to another party. Such reselling results in overestimation of cross-border securities activity even if reporters follow instructions precisely and have all necessary information. For example, the resale of "borrowed" securities can result in two different foreign residents being reported on a liabilities survey as holding the same U.S. security, or it can result in the same U.S. security being reported as having been purchased twice by foreign residents with no intervening sale. Possible approaches to compensat- ing for this conceptual flaw in the U.S. system are to have borrowers that resell these securities report a "short" (or negative) position or to treat such "borrowings" as outright purchases and sales. Neither approach is a perfect solution. The first raises concerns about whether "short" positions can be accurately measured. The second elicits reluctance to cease considering these transactions collateralized loans because, in the economic sense, such treatment accurately characterizes their nature.

Although the TIC system does not measure overall levels of repo and securities lending transactions, they are known to be substantial. For example, it has been estimated that as of February 1999, approximately 41 percent of U.S. government securities were on repo and another 14 percent were on loan. ${ }^{10}$ Given the magnitude of these activities, it is clear that misreporting of data concerning these transactions either on the surveys or in the aggregate transactions reports could produce significantly inaccurate data. The extent to which errors may be occurring because of such activity is unknown but is of ongoing concern.

\section{Maintenance of Adequate Coverage}

Although a significant and increasing level of resources is devoted to collecting and editing the TIC data, U.S. cross-border financial flows are becoming increasingly difficult to measure accurately. In the not-too-distant past, most cross-border financial transactions occurred through a relatively small and readily identifiable group of banks and brokerdealers. But the number and types of direct market participants continue to grow as regulatory impediments are removed, financial information is increasingly available, and transaction costs decline. Measuring the activities of a diverse and changing group of market participants is much more difficult, especially as the channels through which cross-border securities transactions flow are continually evolving. In addition, advances in computerization and other technological developments in financial markets have allowed for the creation of diverse and complex financial instruments that are more difficult to measure accurately. Together, these developments make keeping up with the pace of change increasingly difficult.

10. Bank for International Settlements, Securities Lending Transactions: Market Developments and Implications, joint report of the Technical Committee of the International Organization of Securities Commissions and the Committee on Payment and Settlement Systems of the Group of Ten countries (July 1999), p. 13. 


\section{FUTURE CHANGES IN THE MEASUREMENT OF CROSS-BORDER INVESTMENT IN SECURITIES}

Along with the dramatic growth in the volume and complexity of cross-border financial flows over the past twenty years has come growing recognition of the need for more comprehensive, more accurate, and more timely data. To be most useful, the data should be comparable across countries. To facilitate comparability, many efforts to improve data are being channeled through international organizations such as the International Monetary Fund (IMF) and the Bank for International Settlements, as well as the European Central Bank.

Two major initiatives that will affect U.S. efforts to collect statistics on cross-border securities holdings have been initiated under the auspices of the IMF: coordinated portfolio investment surveys and the external debt reporting system. Both initiatives will require that the United States expand its data collection activities and, in some cases, publish results more promptly than in the past.

\section{Coordinated Portfolio Investment Surveys}

The first coordinated portfolio investment survey (CPIS), with data reported as of year-end 1997, was conducted out of concern that holdings of foreign portfolio assets were being undercounted. Worldwide, measured holdings of portfolio liabilities were much higher than measured holdings of portfolio assets, and the discrepancy was increasing yearly." One suspected reason for the undercount was that countries had placed greater emphasis on measuring foreign holdings of their domestic securities than on measuring domestic holdings of foreign securities. This bias was due in part to concern about the possible influence that foreign holdings might have on the domestic economy. The history of the U.S. collection system illustrates this mismatch in measurement efforts: Modern U.S. surveys of foreign holdings of U.S. securities began in 1974, but the first modern survey of U.S. holdings of foreign securities was not conducted until 1994. A second possible explanation for the undercount is underreporting by domestic residents so as to avoid taxes (domestic issuers of securities have no similar incentive to underreport their liabilities to foreigners).

11. See International Monetary Fund, Final Report of the Working Party on Statistical Discrepancies in the World Current Account Balance [Estava Report] (1987) and Final Report of the Working Party on the Measurement of International Capital Flows [Godeaux Report] (1992).
To address the measurement mismatch, the IMF invited major industrial and financial center countries to participate in a coordinated effort to measure such holdings. Twenty-nine countries, including the United States, joined in the effort, which became known as the "coordinated portfolio investment survey." 12 The survey found an additional $\$ 750$ billion in cross-border holdings of securities. (Other, less direct benefits of the coordinated surveys are discussed in the box "Collateral Benefits of Coordinated Portfolio Investment Surveys.") However, as the measured worldwide gap between portfolio liabilities and portfolio assets in long-term securities still stood at $\$ 1.7$ trillion, work clearly remains to be done.

One of the key shortcomings of the first CPIS was the lack of participation by countries recognized as offshore financial centers, whose holdings are believed to be quite large but cannot be accurately estimated (among those countries, only Bermuda participated). For this and other reasons, it was decided to repeat the CPIS as of year-end 2001, to make a major effort to increase survey participation, to measure holdings of short-term as well as long-term securities, and to produce survey results more quickly. As of September 2001, it appears that participation in the year-end 2001 survey will be considerably greater, with sixty countries indicating their willingness to participate, including most of the major offshore financial center countries.

For the United States, the upcoming CPIS will mark the first time that both short-term and longterm securities are measured by a portfolio survey. The United States will also try to provide survey results more promptly. In the past, survey results have been produced with lags of at least a year because of the inherent complexity of the surveys, the large amount of data collected, start-up problems encountered by both reporters and compilers due to surveys being conducted at widely spaced intervals, and the three-month period between the survey "as of" date and the date when reporters must submit their data. All CPIS-participating countries will attempt to provide results within nine months of the survey "as of" date, with the IMF publishing findings within three months thereafter.

Although no decision has yet been made to conduct coordinated surveys after the upcoming survey,

12. The participating countries were Argentina, Australia, Austria, Belgium, Bermuda, Canada, Chile, Denmark, Finland, France, Iceland, Indonesia, Ireland, Israel, Italy, Japan, Korea, Malaysia, Netherlands, New Zealand, Norway, Portugal, Singapore, Spain, Sweden, Thailand, United Kingdom, United States, and Venezuela. Survey results were published by the IMF in Results of the Coordinated Portfolio Investment Survey (International Monetary Fund, 1999). 


\section{Collateral Benefits of Coordinated Portfolio Investment Surveys}

Aside from the direct benefits to a country of periodically measuring its residents' holdings of foreign securities, the coordinated portfolio investment surveys (CPIS), conducted under the auspices of the International Monetary Fund, have had several significant, though indirect, beneficial effects. One of these is the spread of best practices. Data compilers for the participating countries, previously largely isolated from one another, have, as a result of the coordinated surveys, come into contact. This contact has afforded representatives of countries experienced in such surveys the opportunity to exchange ideas and discuss problems, and for those less experienced to learn from others. Such contact may well have encouraged some countries to improve their procedures. Also, IMF support has made it possible for some countries to assign additional resources to collection efforts.

The CPIS group is exploring the use of counterparty data to supplement domestic survey data. Prompting the study is the inherent gap in the measurement of holdings of foreign securities resulting from the impracticality of surveying all resident entities. An example is an instance of a resident of Argentina purchasing a French security and entrusting the security's safekeeping to a custodian in the United States. Under current CPIS practice, such a holding will not be recorded. Argentine compilers will not detect the holding, as neither that country nor any other country attempts to directly measure individual investors' holdings (because of cost and privacy concerns). French compilers will probably measure the holding as a liability to the United States. However, U.S. compilers will not report the security on the CPIS survey, as the survey measures holdings of foreign securities by residents of the reporting country, and this is a holding of a foreign security by a foreign resident. Thus, a cross-border liability will be recorded without an offsetting asset being recorded. The possibility of closing this gap by having custodians in each country report holdings of foreign securities by certain classes of nonresident investors and exchanging the information with counterparty countries is being investigated by the CPIS group. The problem is complicated by the lack of legal authority for such data collection in some cases and by the possibility of double-counting under certain circumstances.

Another area being studied is the reduction of reporting errors associated with repurchase and securities lending agreements. These transactions can easily lead to doublecounting or undercounting of holdings. Major financial center countries are working together to better understand the mechanics of these transactions and to develop a common approach to obtaining better data.

The CPIS group is also exploring the possibility of creating a centralized database of all exchange-traded securities that could be used by national compilers worldwide to help conduct the coordinated surveys. Currently, CPIS surveys are conducted in two fundamentally different ways. Some countries (including the United States) collect data securityby-security, which allows for detailed editing and analysis. Other countries collect data in the aggregate, which allows for the detection of only relatively egregious errors and provides fewer opportunities for examining the structure and patterns of foreign securities holdings. Believing that the security-level approach produces more reliable results, the International Monetary Fund and the European Central Bank are exploring ways to make it easier for countries to conduct security-level surveys. A centralized database could facilitate security-level surveying by providing to participating countries, at little or no cost, information that could be used to cross-check and supplement reported data.

As important as the spread of best practices and the group efforts toward improvement are, perhaps the most important benefit of the coordinated surveys is that many participating countries have begun to conduct portfolio asset surveys on a regular basis, and others will begin to do so in the near future. Taken together, these efforts demonstrate the importance of international cooperation and coordination to help national compilers understand the workings of an increasingly complex international financial system. Market participants will continue to innovate and operate on a worldwide basis, and national compilers, who must continually attempt to understand and adjust to these changes with relatively limited resources, are in a far better position to respond appropriately if they act cooperatively. it is likely that such surveys will become ongoing activities. During discussions on the future of coordinated surveys, the United States committed to conducting asset surveys at least once every three years and to consider conducting them annually.

\section{External Debt Reporting System}

The coordinated surveys are designed to improve data on holdings of foreign assets. Another initiative, the external debt reporting system, is designed to improve data on liabilities to foreigners. This system is part of the IMF's Special Data Dissemination Standard (SDDS), and all countries that subscribe to the SDDS are obligated to provide required elements of the system. ${ }^{13}$ Although the system will measure a

13. In September 2001, forty-nine countries were subscribers to the SDDS. A list of those countries is given at http://dsbb.imf.org/ country.htm. Additional information on the SDDS is available on the IMF web site, at http://dsbb.imf.org/sddsindex.htm. 
wide range of financial liabilities to foreigners, only those aspects pertaining to the measurement and reporting of foreign holdings of U.S. securities are discussed here.

The external debt reporting system was developed in large part in response to the financial crises of 1997-98 in Asia, Russia, and Brazil. These crises, which took most of the financial community by surprise, sparked an extensive postmortem in an attempt to discern the reasons these events were not more widely foreseen. Identified as a major contributing factor was the lack of key data that might have provided an early warning.

The external debt reporting system was approved by the IMF's executive board in March 2000 after prolonged discussion and is scheduled to become operational in September 2003. The long lead-time is intended to give national compilers time to make the necessary enhancements to their reporting systems, which for many countries, including the United States, will be significant.

The system requires quarterly reporting, with a one-quarter lag, on both long-term and short-term debt securities held by foreigners (with long-term securities defined as those with an original term to maturity of more than of one year). Liabilities are to be reported separately for four sectors: general government, monetary authorities, banks, and "other." In addition to the required data, countries are encouraged to provide other types of information. Most prominent among these encouraged elements are data on forward debt service schedules and a breakdown of external debt in terms of domestic currency and foreign currency components, both of which the United States has decided to provide.

To meet the requirements, the United States will begin to conduct liabilities surveys annually instead of at five-year intervals, and the surveys will, for the first time, collect data on foreign holdings of shortterm as well as long-term securities. These surveys will be somewhat scaled down from the previous liabilities surveys, however, and will rely on estimation as well as measurement in four out of every five years to reduce costs to both respondents and compilers. The detailed, security-by-security data collected by the surveys will be combined with the monthly aggregate transactions data to produce estimates of the required data for the quarters for which no survey data are available.

The U.S. monthly reporting system will also be enhanced to help meet SDDS requirements. Current SDDS guidelines specify that components of external debt be presented according to the institutional sector of the debtor, the maturity structure (short-term or long-term), and the type of financial instrument. The TIC report forms that cover short-term instruments do not easily comport with these attributions and will need to be modified.

\section{Other Changes under Consideration}

In addition to the enhancements to the U.S. reporting system associated with the CPIS and the external debt reporting system, other possible changes are on the horizon. The first broad-based review of the TIC system in more than twenty years has recently been completed. The review has produced two recommendations pertaining to cross-border securities measurement: Portfolio asset surveys should be conducted annually, and reporting on purchases and sales of foreign securities should be based on the country of the issuer of the security instead of the country of the foreign counterparty to the transaction.

The first recommendation is based on the belief that the benchmark surveys give a more accurate picture of U.S. holdings of foreign securities than do calculations based on the monthly transactions reports. It is supported by the fact that both asset surveys to date have measured greater holdings than were predicted by estimates based on price- and exchange-rate-adjusted transactions data, and by recognition that it is increasingly easy for U.S. investors to purchase or sell foreign securities without the assistance of a U.S. financial intermediary.

The second recommendation is based on the belief (and supported by conversations with data users) that for analytical purposes, information on which country's securities U.S. residents are buying and selling is more useful than information on where they are buying and selling foreign securities. Some major institutions that are primary reporters of such information have indicated that they envision no major problems in making the switch. The switch cannot be made for foreign purchases of U.S. securities, however, because U.S. reporters do not have information on the resident country of the actual buyer or seller, but know only the country in which the foreign transactor is located.

\section{CONCLUSION}

The TIC data on cross-border securities activity are extremely useful in understanding the actions of both 
U.S. and foreign investors. The monthly transactions reports provide timely information on recent activity, and the benchmark surveys give detailed insight into cross-border investment patterns.

The system is able to address with some certainty questions concerning aggregate holdings, such as the extent of foreign ownership of U.S. firms and the level of foreign securities in U.S. investors' portfolios, because this information is provided by security-level data collected via the benchmark surveys. The security-level data can also provide a very accurate picture of the distribution of U.S. investors' foreign portfolios by country; but they are less accurate in the country attribution of foreign investors in U.S. securities, because of a custodial center bias in the liabilities surveys. Finally, the benchmark surveys provide insight into the composition of cross-border holdings. However, because the surveys are infrequent and involve considerable editing and processing, the data are not available on a timely basis.

The monthly transactions reports, though providing timely information on cross-border flows, must be interpreted with some caution, primarily because that portion of the data collection system is governed by balance of payments conventions. For example, because the system was designed to capture market transactions only, data on equities acquired through stock swaps are not collected, though they are important in analyses of portfolio flows. Moreover, because the system identifies the country of the transactor, the data contain a financial center bias that must be accounted for in analyses of bilateral portfolio flows, studies of the determinants of flows between the United States and any specific country or area, and examinations of the effects of these flows on bilateral exchange rates. Finally, it appears that the transactions data may understate net U.S. purchases of foreign securities, especially equity issues, and that recent transactions data may have overstated net foreign purchases of U.S. securities, especially debt instruments.

As cross-border trading has grown in volume, complexity, and importance, the need to modify the U.S. system to produce more comprehensive, timely, and accurate data has become increasingly evident. Some enhancements and improvements have been decided on, and others are being considered. At the same time, the U.S. system is evolving from one that has operated largely in isolation from those in other countries into one that is increasingly harmonized with, and affected by, international efforts to improve data on cross-border securities activities.

\section{APPENDIX: USING TRANSACTIONS DATA TO ESTIMATE HOLDINGS}

Cross-border holdings of equity and long-term debt at the end of a month can be estimated by adjusting the preceding month's holdings for estimated changes in prices and exchange rates, adding the current month's (transaction-cost-adjusted) net purchases, and, in the case of equities, adding acquisitions through stock swaps. Specifically, cross-border holdings of a particular type of instrument (foreign equity, foreign debt, U.S. equity, U.S. Treasury debt, U.S. agency debt, or U.S. corporate or municipal debt) at the end of period $t$ can be estimated by the equation

$$
\begin{aligned}
A_{i, i}= & A_{i, t-.} \quad R_{i, t} / R_{i, t-1} \\
& +N P_{i, t} \cdot\left[1-\left(G P_{i, t}+G S_{,, t}\right) \cdot T_{i}\right] \\
& +S S_{i, t}
\end{aligned}
$$

where the subscript $i$ denotes the foreign country. When estimating U.S. holdings of foreign securities, $i$ denotes the country in which the security was issued; when estimating foreign holdings of U.S. securities, it denotes the country of the foreign investor. The variables are defined as follows (definitions when estimating foreign holdings of U.S. securities are given in parentheses):

$$
\begin{aligned}
A_{i, i}= & \text { Holdings of country } i \text { 's securities by U.S. } \\
& \text { residents at the end of month } t \text { (holdings } \\
& \text { of U.S. securities by country } i \text { 's residents } \\
& \text { at the end of month } t \text { ) } \\
R_{i,:}= & \text { Price index for revaluing holdings } \\
N P_{i,:}= & \text { Net purchases of country } i \text { 's securities } \\
& \text { by U.S. residents during month } t \text { (net } \\
& \text { purchases of U.S. securities by country } \\
& i \text { 's residents during month } t \text { ) } \\
G P_{:,:}= & \text {Gross purchases of country } i \text { 's securities } \\
& \text { by U.S. residents during month } t \text { (gross } \\
& \text { purchases of U.S. securities by country } \\
& i \text { 's residents during month } t \text { ) }
\end{aligned}
$$ by U.S. residents during month $t$ (gross purchases of U.S. securities by country $i$ 's residents during month $t$ )

Nôte. The discussion and data in this appendix are from F.E. Warnock and C.A. Cleaver, "Financial Centers and the Geography of Capital Flows." International Finance Discussion Paper (Board of Governors of the Federal Reserve System, Division of International Finance, forthcoming). 


$$
\begin{aligned}
G S_{i,:}= & \text { Gross sales of country } i \text { 's securities } \\
& \text { by U.S. residents during month } t \\
& \text { (gross sales of U.S. securities by country } \\
& i \text { 's residents during month } t \text { ) }
\end{aligned}
$$

\section{$T_{i}=$ Adjustment factor for transaction costs}

$$
\begin{aligned}
S S_{i, 1}= & \text { Country } i \text { 's equities acquired by U.S. } \\
& \text { residents through stock swaps during } \\
& \text { month } t \text { (U.S. equities acquired by } \\
& \text { country } i \text { 's residents through stock } \\
& \text { swaps during month } t \text { ). }
\end{aligned}
$$

The use of this procedure is illustrated by estimating holdings of foreign securities by U.S. residents as of December 31, 1997, from measured holdings on March 31, 1994, and holdings of U.S. securities by residents of other countries as of March 31, 2000, from measured holdings on December 31, 1994.

Data for some of the variables are readily available: Initial values of $A_{i}$ are given by the 1994 benchmark surveys, and purchases and sales figures are from the monthly transactions reports; data on equities acquired through stock swaps are from Securities Data Corporation.

Appropriate values for two of the variables are unknown: the price index for revaluing holdings and transaction costs incurred by investors in cross-border transactions. The price index used for revaluing holdings should reflect the composition of cross-border holdings. Unfortunately, the compositions can be determined only for survey dates, as the monthly transactions data do not indicate which equities and debt securities U.S. and foreign investors are trading. Having little information to rely on, we revalue equity holdings using MSCI indexes, because they are typically composed of the larger, more actively traded equities - the type of equities foreigners might be more likely to hold. For revaluing debt holdings, we use indexes from J.P. Morgan and Lehman Broth- ers. For transaction costs in equities, we use estimates of commissions and fees charged institutional investors provided by Elkins-McSherry. For transaction costs in U.S. debt securities, we use half the bid-ask spread and rely on estimates of spreads provided by market participants of 5 basis points (BP) on U.S. Treasury debt, 10 BP on U.S. agency debt, and 25 BP on U.S. corporate debt. And for transaction costs in foreign debt securities, we use information on bidask spreads from the Bank for International Settlements and J.P. Morgan if it is available; if it is not available, we assume spreads of $25 \mathrm{BP}$ for industrial countries and $50 \mathrm{BP}$ for emerging market countries.

\section{Aggregate Estimates}

As estimated by the equation, aggregate foreign holdings of U.S. long-term securities as of March 31, 2000 , totaled almost $\$ 4.2$ trillion, 16 percent higher than the amount measured by the benchmark survey as of the same date (table A.1). ${ }^{14}$ Much of the difference is due to overestimation of foreign holdings of U.S. debt securities, which in turn is due to the large amount of net purchases ( $\$ 1.4$ trillion). The estimate of foreign holdings of U.S. equities, in contrast, is very close to the amount measured by the benchmark survey, especially considering the large valuation adjustment. ${ }^{15}$

The apparent overcounting of net foreign purchases of U.S. debt securities has at least three pos-

14. Official year-end estimates of cross-border holdings are published by the BEA in its presentation of the international investment position; the BEA does not publish quarterly estimates. Our estimates would differ from the BEA's for many reasons. For example, the BEA might choose different price indexes or use different assumptions

\begin{tabular}{|c|c|c|c|c|c|c|c|c|}
\hline \multirow{3}{*}{ Type of security } & \multirow{2}{*}{$\begin{array}{c}\text { December 31, } \\
1994 \\
\text { Measured }\end{array}$} & \multicolumn{4}{|c|}{ January 1995-March 2000} & \multicolumn{3}{|c|}{ March 31,2000} \\
\hline & & Net purchases & $\begin{array}{l}\text { Transaction } \\
\text { costs }\end{array}$ & Stock swaps & $\begin{array}{l}\text { Valuation } \\
\text { adjustment }\end{array}$ & $\begin{array}{l}\text { Estimated } \\
\begin{array}{l}(1+2- \\
3+4+5)\end{array}\end{array}$ & Measured & $\begin{array}{l}\text { Estimated } \\
\text { less measured } \\
(6-7)\end{array}$ \\
\hline & (1) & (2) & (3) & (4) & (5) & (6) & (7) & (8) \\
\hline Debt & 846 & 1,444 & 16 & .. & 3 & 2,277 & 1,865 & 412 \\
\hline Equity & 398 & 314 & 14 & 66 & 1,132 & 1,895 & 1,711 & 184 \\
\hline Total & 1,244 & 1,758 & 30 & 66 & 1,135 & 4,172 & 3,576 & 596 \\
\hline
\end{tabular}
about transaction costs.

15. The $\$ 184$ billion difference between estimated and measured equity holdings could be due to just a 19 percent overestimation of the cumulative valuation adjustment on foreigners' holdings of U.S. equities over the five-year period, a small amount given the 240 percent increase in U.S. stock prices over the period.

A.1. Measured and estimated value of foreign holdings of U.S. long-term securities, by type of security, March 31, 2000 Billions of dollars

\footnotetext{
.. Net applicialylis.
} 
A.2. Measured and estimated value of U.S. holdings of foreign long-term securities, by type of security, December 31,1997 Billions of dollars

\begin{tabular}{|c|c|c|c|c|c|c|c|c|}
\hline \multirow{3}{*}{ Type of security } & \multirow{2}{*}{$\begin{array}{c}\text { March 31, } \\
1994 \\
\text { Measured }\end{array}$} & \multicolumn{4}{|c|}{ April 1994-D.wember 1997} & \multicolumn{3}{|c|}{ Г. ecember $31,199 ?$} \\
\hline & & Net purchases & $\begin{array}{c}\text { Transaction } \\
\text { costs }\end{array}$ & Stock swaps & $\begin{array}{c}\text { Valuation } \\
\text { adjustment }\end{array}$ & $\begin{array}{c}\text { Estimated } \\
(1+2- \\
3+4+5)\end{array}$ & Measured & $\begin{array}{l}\text { Estimated } \\
\text { less measured } \\
(6-7)\end{array}$ \\
\hline & (1) & (2) & (3) & (4) & (5) & (6) & (7) & (8) \\
\hline Debt & 304 & 159 & 7 & . & 48 & 504 & 547 & -43 \\
\hline Equity & 567 & 181 & 8 & 5 & 228 & 973 & 1,208 & -235 \\
\hline Total & 871 & 340 & 15 & 5 & 276 & 1,477 & 1,755 & -278 \\
\hline
\end{tabular}

... Nest applisisuls:

sible explanations. The first is associated with assetbacked securities. Many U.S. debt securities are backed by pools of loans (such as residential mortgages, automobile loans, or credit card receivables) placed in trust. On these securities, both the principal and the interest are repaid on a regular basis (usually monthly), so the amount of principal held by foreign (and domestic) owners of these securities decreases each month. If these principal paydowns are not accurately captured in the transactions data, holdings of asset-backed securities will be overstated. Overcounting of securities involved in repurchase and securities lending agreements is a second possible explanation for the apparent overcounting of net foreign purchases of debt securities, although the possible magnitude of the error is unknown. The third possible explanation is a failure to report redemptions of foreign-held securities.

Whereas foreign holdings of U.S. securities are overestimated, U.S. holdings of foreign securities as of year-end 1997-the date of the most recent asset survey—are underestimated, by almost $\$ 300$ billion (table A.2). Doubling the valuation adjustments for debt and equity holdings would bring the estimates in line with the measured amounts, but it is unlikely that the valuation adjustments used are off by a factor of two over the almost-four-year period between asset surveys. Rather, it seems likely that net purchases of foreign securities are being undercounted in the monthly transactions data, perhaps because an evergrowing number of U.S. investors are participating directly in foreign securities markets as a result of improvements in international communications and their transactions are not recorded in the monthly TIC reports. ${ }^{16}$ Automatic purchases, such as with dividends reinvestment plans (or DRIPs), are also likely undercounted.

16. This observation has also been made by Lois Stekler, in "Adequacy of International Transactions and Position Data for Policy Coordination," in W. Branson, J. Frenkel, and M. Goldstein, eds., International Policy Coordination and Exchange Rate Fluctuations (National Bureau of Economic Research and University of Chicago Press, 1990).

A.3. Measured and estimated value of U.S. holdings of foreign long-term securities, December 31, 1997 Billions of dollars

\begin{tabular}{|c|c|c|c|c|c|c|}
\hline \multirow{2}{*}{ Country or region } & \multicolumn{2}{|c|}{ De $: L$} & \multicolumn{2}{|c|}{ Equity } & \multicolumn{2}{|c|}{ To.al } \\
\hline & Measured & Estimated & Measured & Estimated & Measured & Estimated \\
\hline $\begin{array}{l}\text { Financial centers } \\
\quad \text { United Kingdom } . . . \ldots . . \\
\text { Caribbean } \quad \cdots \ldots \ldots \ldots \\
\text { Hong Kong } \quad \ldots \ldots \ldots \ldots\end{array}$ & $\begin{array}{r}54 \\
22 \\
4\end{array}$ & $\begin{array}{r}68 \\
25 \\
0\end{array}$ & $\begin{array}{r}218 \\
49 \\
28\end{array}$ & $\begin{array}{r}244 \\
32 \\
27\end{array}$ & $\begin{array}{r}272 \\
71 \\
32\end{array}$ & $\begin{array}{r}311 \\
57 \\
27\end{array}$ \\
\hline $\begin{array}{l}\text { Industrial countries } \\
\quad \text { Euro area } \ldots \ldots \ldots \ldots \ldots \\
\text { Other Europe } \ldots \ldots \ldots \ldots \\
\text { Japan } \ldots \ldots \ldots \ldots \ldots \ldots \ldots \\
\text { Canada } \ldots \ldots \ldots \ldots \ldots \ldots\end{array}$ & $\begin{array}{r}116 \\
27 \\
30 \\
107\end{array}$ & $\begin{array}{r}110 \\
24 \\
36 \\
91\end{array}$ & $\begin{array}{r}376 \\
125 \\
136 \\
71\end{array}$ & $\begin{array}{r}256 \\
99 \\
94 \\
73\end{array}$ & $\begin{array}{l}492 \\
153 \\
166 \\
178\end{array}$ & $\begin{array}{l}366 \\
123 \\
130 \\
164\end{array}$ \\
\hline $\begin{array}{l}\text { Emerging markets } \\
\text { Asia ................. } \\
\text { Latin America . }\end{array}$ & $\begin{array}{l}30 \\
89\end{array}$ & $\begin{array}{l}26 \\
83\end{array}$ & $\begin{array}{l}30 \\
89\end{array}$ & $\begin{array}{l}14 \\
77\end{array}$ & $\begin{array}{r}60 \\
178\end{array}$ & $\begin{array}{r}40 \\
160\end{array}$ \\
\hline Other & 68 & 41 & 86 & 57 & 153 & 99 \\
\hline Total & 547 & 504 & 1,208 & 973 & 1,755 & 1,477 \\
\hline
\end{tabular}


A.4. Measured and estimated value of foreign holdings of U.S. long-term securities, March 31, 2000 Billions of dollars

\begin{tabular}{|c|c|c|c|c|c|c|}
\hline \multirow{2}{*}{ Country or region } & \multicolumn{2}{|c|}{ De:t } & \multicolumn{2}{|c|}{ Eq.uity } & \multicolumn{2}{|c|}{ To.al } \\
\hline & Measured & Estimated & Measured & Estimated & Measured & Estimated \\
\hline 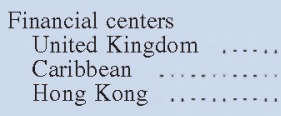 & $\begin{array}{r}203 \\
160 \\
58\end{array}$ & $\begin{array}{r}660 \\
212 \\
66\end{array}$ & $\begin{array}{r}322 \\
142 \\
19\end{array}$ & $\begin{array}{r}497 \\
181 \\
15\end{array}$ & $\begin{array}{r}525 \\
302 \\
77\end{array}$ & $\begin{array}{r}1,157 \\
393 \\
81\end{array}$ \\
\hline $\begin{array}{l}\text { Industrial countries } \\
\text { Euro area } \ldots \ldots \ldots \ldots \ldots \\
\text { Other Europe } \ldots \ldots \ldots \ldots \\
\text { Japan } \ldots \ldots \ldots \ldots \ldots \ldots \ldots \\
\text { Canada }\end{array}$ & $\begin{array}{r}279 \\
57 \\
283 \\
35\end{array}$ & $\begin{array}{r}298 \\
54 \\
372 \\
50\end{array}$ & $\begin{array}{l}452 \\
197 \\
145 \\
173\end{array}$ & $\begin{array}{l}433 \\
241 \\
112 \\
182\end{array}$ & $\begin{array}{l}731 \\
253 \\
429 \\
208\end{array}$ & $\begin{array}{l}731 \\
295 \\
484 \\
232\end{array}$ \\
\hline $\begin{array}{l}\text { Emerging markets } \\
\text { Asia ............... } \\
\text { Latin America }\end{array}$ & $\begin{array}{r}152 \\
37\end{array}$ & $\begin{array}{r}123 \\
46\end{array}$ & $\begin{array}{l}10 \\
14\end{array}$ & $\begin{array}{r}8 \\
29\end{array}$ & $\begin{array}{r}163 \\
51\end{array}$ & $\begin{array}{r}131 \\
76\end{array}$ \\
\hline Other & 278 & 394 & 194 & 197 & 471 & 590 \\
\hline Country unknown & 323 & $\ldots$ & 43 & $\ldots$ & 366 & $\ldots$ \\
\hline Total & 1,865 & 2,277 & 1,711 & 1,895 & 3,576 & 4,172 \\
\hline
\end{tabular}

.. Net applisualls.

\section{Bilateral Estimates}

Because benchmark surveys of U.S. holdings of foreign securities accurately indicate the country of the issuer, deviations of estimated holdings from measured holdings by country are due to the limitations of the transactions data resulting from current TIC reporting conventions. For U.S. holdings of foreign debt securities, the estimates, by country, are relatively close to the measured amounts; holdings of U.K. debt are overestimated by 17 percent, but, overall, the estimates are roughly in line with the survey data (table A.3). U.S. holdings of U.K. equities are also overestimated, but U.S. holdings of equities from most other areas are underestimated, in some cases strikingly so. For example, holdings of equities issued by companies in the euro area and Japan are underestimated by more than 30 percent.

Because of the bias in benchmark surveys of foreign holdings of U.S. securities toward custodial centers, the country attribution in the liabilities survey data is not perfect. That said, the figures show a substantial overestimation of holdings of U.S. securities by financial centers (table A.4). Indeed, estimated U.K. holdings of U.S. debt based on transactions data are more than three times the measured amount. ${ }^{17}$

17. Some portion of the measured holdings labeled "Country unknown" may be attributable to bearer bonds held by U.K. residents.
Holdings of U.S. equities show a similar pattern, with the overestimation of U.K. holdings totaling $\$ 175$ billion. Estimated holdings of U.S. securities in the Caribbean financial centers are also too high. For the other countries included in table A.4, the estimates are somewhat closer to the measured amounts, with the exceptions of U.S. debt held in Japan and emerging Asia and U.S. equities held in Japan, "Other Europe," and Latin America.

The fact that the bilateral transactions data appear to be biased toward financial centers must be acknowledged in any analysis of bilateral capital flows. An obvious solution is to exclude financial centers (such as the United Kingdom) from the analysis. But this solution is unsatisfactory, as other countries (such as euro area countries) are also affected. For example, if many transactions between the euro area and the United States go through the United Kingdom, how should studies of the determinants of flows between the euro area and the United States, or of the effects of capital flows on the dollar-euro exchange rate, be interpreted? 